\title{
JUURNAL.RU
}

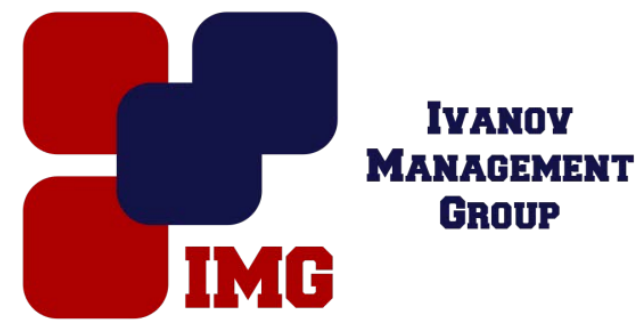

Мощенко А.В., Шмат Е.В. Омский государственный аграрный университет Омск, Россия

doi: 10.18411/lj-30-04-2017-2-10

idsp 000001:1j-30-04-2017-2-10

\section{Ветеринарно-санитарная оценка сливочного масла по классификациям и ассортименту}

\begin{abstract}
Аннотация
Сливочное масло - пищевой продукт, представляющий собой концентрат молочного жира. Масло отличается своей легкой усвояемостью по отношению с другими животными жирами, обладает высокой энергетической ценностью. Сливочное масло из коровьего молока вырабатывают двумя методами: сбиванием сливок жирностью (28-42\%) в маслоизготовителях периодического и непрерывного действия или методом термохимического преобразования высокожирных сливок $(82,5 \%)$.

Ключевые слова: сливочное масло, классификация, ассортимент, виды.

Масло, получаемое из коровьего молока, разделяют на сливочное и топленое. Сливочное масло получают из сливок свежих или, которые были сквашены чистыми культурами молочнокислых бактерий.

Сливочное маслоделится на виды: - Сладко-сливочное (соленое и несоленое) - получают из свежих пастеризованных сливок: количество жира не ниже 82,5\%, влаги - не выше 16\%; - Кислосливочное (соленое и несоленое) производят из сквашенных пастеризованных сливок: жира - не ниже 82,5\%, влаги - не выше 16\%; - Вологодское - сладкосливочное несоленое масло, имеет ярко выраженный аромат пастеризованных сливок и «ореховый» привкус, такие свойства объясняются длительной высокотемпературной пастеризацией сливок: жира - не ниже 82,5\%, влаги - не выше 16\%; - Любительское (соленое и несоленое; сладкосливочное и кислосливочное): количество жира - не ниже
\end{abstract}


78\%, влаги - не выше 20\%; - Крестьянское (сладкосливочное соленое и несоленое; кислосливочное несоленое): жира - не ниже 72,5\% (в несоленом) и $71,5 \%$ (в соленом), влаги - не выше 25\%; - Бутербродное масло (сладкосливочное и кислосливочное несоленое): жира - не ниже $61,5 \%$, влаги не выше $35 \%$; - Шоколадное масло: количество жира - не ниже $62 \%$, влаги - не выше $16 \%$, сахара - не ниже $18 \%$, какао - не ниже $2,5 \%$; - С различными вкусовыми наполнителями (фруктово-ягодное, медовое и др.); - С частичной заменой молочного жира растительным маслом (диетическое, домашнее и др.).

Сливочное масло в зависимости от используемого исходного сырья, помимо сливочного масла и топленого масла (изготавливают при перетапливании сливочного или подсырного масла), делят еще на подсырное масло (полуфабрикат маслодельной промышленности) и на восстановленное масло (вырабатывают из топленого масла и молочной плазмы).

Сегодняшний ассортимент сливочного масла разнообразен широким спектром новых видов масла с различными вкусовыми вариантами. На прилавках нашего города (г. Омск) в основном представлены следующие виды сливочного масла: «Крестьянское», «Вологодское», «Любительское», «Шоколадное» «Фруктовое», а так же большой ассортимент спредовой продукции.

1. Мамаев А.В., Самусенко Л.Д. Молочное дело: учебное пособие / А.В. Мамаев, Л.Д. Самусенко. - СПб. : Издательство Лань, 2013.- 384 с.

2. Технический регламент Таможенного союза "О безопасности молока и молочной продукции" (ТР ТС 033/2013) [Электронный ресурс]. - Введ. 2013-10-09. - Режим доступа: http://docs.cntd.ru/document/499050562, свободный. - Заглав. с экрана.

3. Шмат Е.В., Заболотных М.В., Корниенко Е.В. Электронное учебное пособие «Производственный ветеринарно-санитарный контроль»/ Шмат Е.В., Заболотных М.В., Корниенко Е.В. - Хроники объединенного фонда электронных ресурсов Наука и образование, 2015.- С.71. 